\title{
The Contribution of Scientific Project Competitions upon High School Students' Acquiring a Scientific Viewpoint (Geography Lesson Case)
}

\author{
Ali Meydan ${ }^{1}$ \\ ${ }^{1}$ Faculty of Education, Nevsehir Haci Bektas Veli University, Nevsehir, Turkey \\ Correspondence: Ali Meydan, Faculty of Education, Nevsehir Haci Bektas Veli University, 2000 Evler Mah., \\ Zübeyde Hanim Cad., 50300, Nevsehir, Turkey. Tel: 90-384-228-1000. E-mail: alimeydan01@gmail.com
}

Received: January 20, 2017

Accepted: Februaty 5, 2017

Online Published: March 1, 2017

doi:10.5539/jel.v6n2p294

URL: http://doi.org/10.5539/jel.v6n2p294

\begin{abstract}
Scientific research projects competitions for high school students have been held by TUBITAK (The Scientific and Technological Research Council of Turkey) since 1969. Whereas only projects on science were taken into the scope of competition for long years, the projects appropriate to the interdisciplinary approach such as social sciences projects and values education have been started to be included beside science broadening the range since 2000s. In projects, it has been aimed to encourage students studying at high school grade for carrying out studies on basic, social and applied sciences, directing their studies and providing contribution upon the development of current scientific studies. The required qualification is projects' being originated and developed from own knowledge, skill and original thoughts of the students, and being completed by the support of a counselor.

Geography has started to be included in scientific project competitions since 2011. In this research, it was aimed to reveal the importance of secondary education students' scientific project competitions upon their gaining a scientific point of view depending upon the branch of geography. In the research, case study design as one of the qualitative research methods was used. The study group of the research included 38 geography teachers carrying on their duties in Nevsehir province in 2015-2016 academic year. Semi-structured interview technique was used as data collection tool, and the data were analyzed using content analysis method. Obtained quantitative data were digitized, their frequency and percentage were obtained and interpreted.

In the research, it was concluded that participating into scientific project competitions was very beneficial in terms of students, developed viewpoint of students in terms of various aspects, most of the geography teachers considered that the institutions they carried on their duties were adequate for students' developing projects, teachers considered themselves competent for guiding students during the process of preparing the project, and preparing a project provided significant benefits and experiences for the future of students.
\end{abstract}

Keywords: scientific project competition, geography, secondary education students, scientificity

\section{Introduction}

It is necessary to distinguish scientific knowledge from daily knowledge as it is creating the basis for scientific studies. Scientific knowledge that should be justified and verified within the scope of scientific method is required to have a universal quality and be acquired depending upon experiments and observations on our surrounding and the world. Because knowledge is fact-based and obtained with experiments, it reveals cause-result relationship between the events, and is possible to be retested if required.

In Turkish Language Society's Turkish Dictionary, "science" is defined as (1) Regular knowledge, scholarship trying to reveal laws benefiting from reality and methods based upon experiments choosing a specific piece of universe or events; (2) Methodical and systematic knowledge indicating general validity and precision; (3) The methodical researching process for knowledge acquisition aiming a specific purpose arising from the eagerness of knowing a specific subject (Turkish Dictionary, 1998).

According to Demirel (2003), science is regular knowledge including generalizations valid in a specific domain benefiting from experimental methods and objective reality; and body of systematic information obtained through observation and objective measurement of events. And scientific method is the way followed for reaching to the scientific reality. It is research-investigation method including stages such as suggesting 
assumptions related to solving a problem and obtaining some inclusions from these assumptions, testing the solutions, and making evaluations (Demirel, 2003, p. 14).

Project-based learning is one of the teaching methods enabling students to be introduced to science and scientific method supporting their learning by practicing. The education supported with projects prepared by the students is efficient upon creating environments that include long-term interdisciplinary approach instead of teacher-centered classroom implementations, increase interest and eagerness of students, make learning more meaningful and enhance decision-making and self-assessment skills (Morgil, Yavuz, \& Oskay, 2006).

\subsection{Literature Review}

According to Ata (2009, p. 37), project method emerged as a reaction against traditional education (Herbartian method), developed by Kilpatrick in Lincoln School in New York City in 1918, and included activities students thought and planned in order to achieve a goal.

Fairs were primarily started to be used for commercial purposes; however, the number of fairs on educational purposes has recently increased. Especially in America, science fairs organized every year as district-wide, region-wide and state-wide have emerged as significant educational activities increasing the quality of education (Karadeniz, 2012).

Project study should be considered as a supplementary factor for the subjects included in curriculum instead as a contribution upon basic education. In this sense, project study has a remarkable place within the educational program. Modern education emphasizes not enlightenment of students but students' reaching to the capacity of producing information (Özden, 2002, p. 3). Furthermore, it also enables students to reach information on their own by their own experiences benefiting from the previous knowledge, to use the knowledge, to make research, to transfer the knowledge, to present the knowledge combining obtained information appropriately, and to express themselves (Kurak, 2009, p. 10).

The information students who participate into project fairs acquire give them the chance for reaching to large masses, and sharing. Moreover, how they make progress during the project is also revealed. The development noticed in attitudes and behaviors of the students affect the visitors in the fair and give students the chance of reflecting their own personality and ideas. This sharing of students is remarkable in terms of their transferring what they think to others and feeling self-confidence (Maguth \& Yamaguchi, 2010, p. 78).

Science project studies develop students' skills of creating a new product. Moreover, these develop researching skills of the students and help them with sharing their studies and presenting the projects they complete (Karadeniz, 2015, p. 369).

Science fairs are possible to be in different types. The change in science fair projects is related to written agreement report, visual results, oral presentation and evidences. In science fairs, students learn more from what they do. Moreover, these fairs help students to study in a more organized way and improve acquired knowledge to a high level. They share knowledge and experiences they have gained previously. Science fairs proceed in accordance with written reports and well-known procedures; and different learning methods also develop according to personal interests of the students (Cicek, 2008, p. 14). Science fairs and project competitions provide opportunities for students to make research and learning practice. Students develop their skills such as defining a problem, formulizing a hypothesis, collecting data, interpreting the results and making decisions (Camc1, 2008, p. 15).

TUBITAK's purposes of spreading the science to all parts of the society, and discovering and guiding the scientists of future at young ages are possible to be noticed in science society projects and publishing of science and technique journal (www.tubitak.gov.tr, 2016).

Scientific Research Projects Competition for Secondary Education Students has been organized by the Scientific and Technological Research Council of Turkey (TUBITAK) and Turkish Republic Ministry of National Education (MNE) for a long time. The purpose in such competitions is encouraging students upon thinking, observing, being curious and researching what they are curious about and revealing their potentials. However, it is important for the idea as the subject of the project to be revealed by the student/s (TUBITAK, 2011).

The purpose in projects prepared by TUBITAK-Scientist Supporting Directorate is encouraging students upon carrying out studies on basic, social and applied sciences, directing their studies and providing contributions upon the improvement of current scientific studies. For that purpose, projects are organized among high school students on the fields of biology, geography, values education, physics, chemistry, coding, mathematics, psychology, sociology, history, technological design and Turkish language and literature. Moreover, according 
to Science and Technique (2016), students and their counseling teachers who ranked in competitions organized in two stages as both regional finals and Ankara finals have been rewarded.

The students who had national degree on any fields in final competition benefit from additional coefficient implementation proportionally to the grade they get in the competition, in case they choose a department at university related to the grade they had a degree at competition.

The projects to be send to international project competitions by TUBITAK are determined among the ones which have been selected for the final competition. The students who have the first, second and third rank in these projects are placed into the higher education program they request by OSYM (Turkish Higher Education Council) in case they choose a department related to the field that are rewarded (Science \& Technique, 2016, p. 7).

\subsection{Purpose of the Research}

In this research, it was aimed to reveal the importance of scientific project competitions for secondary education students upon students' gaining a scientific point of view.

In accordance with this purpose, the sub-purposes below were determined:

1) What kind of contributions does participating into scientific project competitions for secondary education students provide according to the geography teachers?

2) Do teachers think that projects develop a scientific viewpoint in students? If yes, how?

3) Do geography teachers think whether the sub-structure of the institution they carry on their duty is adequate for preparing projects?

4) Do geography teachers think that they are competent for guiding their students during the process of project preparation?

5) Do geography teachers want to make students carry out a project in a field apart from geography? If yes, on which field and why not on geography?

6) Do the projects have benefits in future of students according to geography teachers?

7) What are the suggestions of geography teachers upon projects?

\section{Method}

This research was carried out on case study model as one of the qualitative research methods. According to Bloor and Wood (2006), case study was a research strategy aiming to understand social phenomenon of an individuals or small group in natural environments (Bloor \& Wood, 2006).

Participants: The participants of the research were 38 geography teachers carrying on their duties in Nevsehir province. The research was carried out with the teachers who attended to "Scientific Project Seminar" organized in November 2015 by Nevsehir Provincial Directorate of National Education for three days.

Table 1. Information related to the study group

\begin{tabular}{llll}
\hline Variables & Participants & f & $\mathbf{\%}$ \\
\hline \multirow{2}{*}{ Gender } & Female & 13 & 34.2 \\
Place of Duty & Male & 25 & 65.8 \\
& Provincial Center & 18 & 47.4 \\
& Districts & 20 & 52.6 \\
& Vocational and Technical & 10 & 26.2 \\
& Anatolian High School & & \\
Type of Assigned School & Vocational High School & 5 & 13.2 \\
& Anatolian High School & 12 & 31.6 \\
& Anatolian Religious High & 3 & 7.9 \\
& School & 3 & 7.9 \\
\hline
\end{tabular}




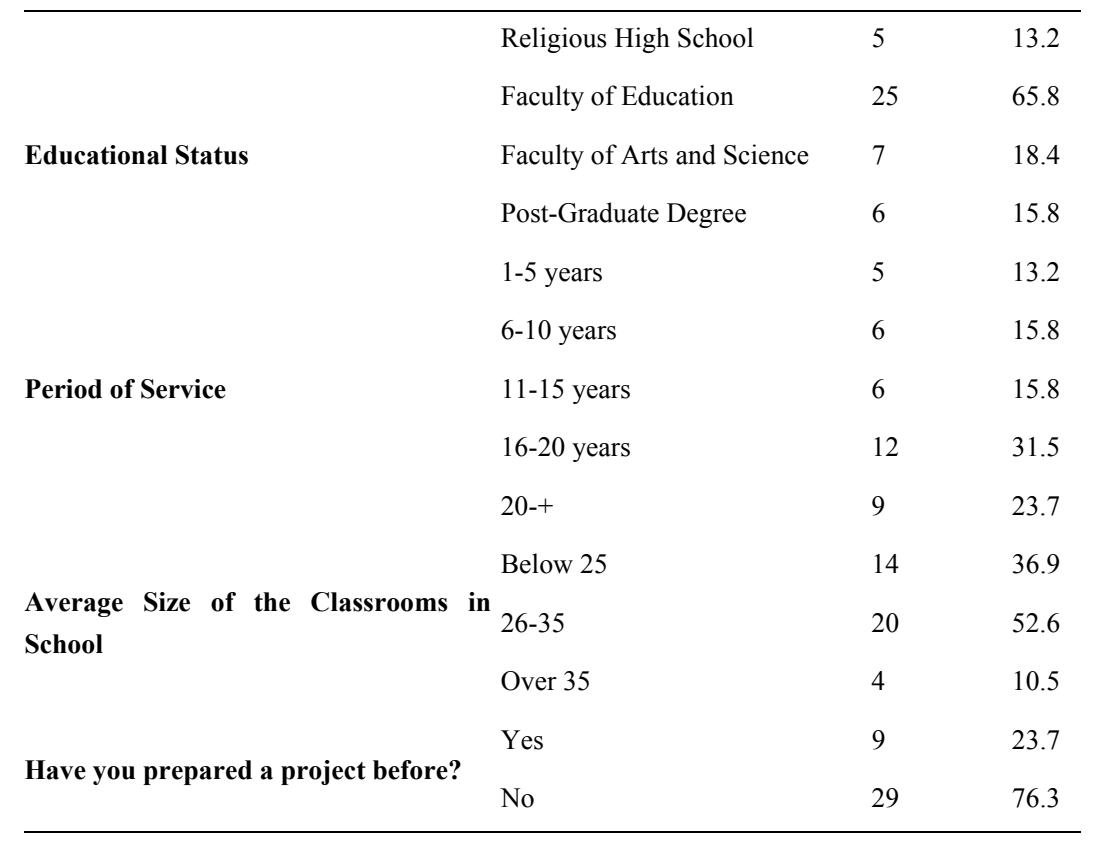

\subsection{Collection and Analysis of Data}

Related to the purpose of the study, a semi-structured interview form including 7 questions developed by the researcher was prepared, and opinions of two experts were asked for the validity of the prepared form. In accordance with the suggestions of experts, the interview form was put into its final form. Teachers were informed about the process and purpose at the beginning of the interview.

The data collected with the interview form were analyzed using content analysis method. Category and themes were created performing the content analysis. Reducing the data to significant parts and naming the parts, combining the codes under broad categories or themes, making comparisons in data graphics, tables and schemes and presenting these were the basic factors of qualitative data analysis (Creswell, 2013). There were four stages in content analysis. These were coding of data, organizing codes and themes, defining the findings and interpretation, respectively (Yildirim \& Simsek, 2011). In this research, each interview form was analyzed before starting to the analysis of data, and the forms were numerated (P1, P2, P3 ...). At which frequency each theme repeated was calculated, and common views were numerically evaluated. Because teachers gave more than one answers to each question, the number of answers (the frequency of expressions) instead of the number of teachers was considered in calculation of frequency. Coding was carried out according to the concepts inferred from data. Interpretation was made after coding (Vyhmeister, 2008). Remarkable data were directly transferred.

\section{Findings and Results}

The data related to the 7 sub-problems included in the research were analyzed, and obtained findings were presented below.

3.1 Finding 1: The Contributions Participating into Scientific Project Competitions for Secondary Education Provided for the Students 
Table 2. Views of geography teachers related to the benefits of participating into scientific project competitions between secondary education students

\begin{tabular}{ll}
\hline Teacher Views & f \\
\hline Gaining self-confidence & 15 \\
Ability of thinking scientifically & 8 \\
Feeling of success & 8 \\
Discovering abilities and skills & 7 \\
Psycho-social development & 6 \\
Developing point-of-view & 6 \\
Gaining power of analytic thinking & 5 \\
Research-analyze abilities & 5 \\
Reasoning and logical thinking & 4 \\
Developing the skill of studying in groups & 4 \\
Providing active learning & 4 \\
Developing problem solving skills & 3 \\
The ability of public speaking & 3 \\
Interrogative approach style & 2 \\
Providing additional score in exams & 2 \\
Strengthening motivation & 2 \\
\hline
\end{tabular}

According to the data in Table 2, teachers mostly expressed that students who participated into the project competitions gained self-confidence, developed their scientific thinking skills and acquired the feeling of success. The opinion of a teacher on this was as: "These are efficient upon students' experiencing increase in their self-confidence, gaining scientific viewpoint, and strengthening the relationship between school and friends." (P9).

According to the teachers, participating into project competitions was a significant factor upon discovering abilities and skills of the students, improving their feeling of success and in their psychosocial development. Whereas one of the teachers mentioned that "These provide increase in self-confidence of students. Being in different environments develop students psychosocially." (P28); the other teacher stated that "Participating into project competitions provide students to gain the feeling of I can achieve, I can manage. These help students to overcome their fear." (P34).

\subsection{Finding 2: Do Teachers Think That Projects Develop a Scientific Point of View in Students? If Yes, How?}

Table 3. Teacher views related to prepared projects' developing a scientific viewpoint in students

\begin{tabular}{lll}
\hline & Reflecting scientific process steps into life & 11 \\
& Developing critical thinking skill & 9 \\
& Prompting to scientific thought & 8 \\
& Establishing the relationship of causality, correlation and distribution & 7 \\
Yes & $\mathbf{2 7} \quad$ Gaining the ability of geographical questioning & 7 \\
& Comprehending that each problem has a cause-result relationship & 7 \\
& Learning the steps of preparing projects & 5 \\
& Developing a project through experiencing & 4 \\
& Learning to review literature & 4 \\
& Thinking different from the previous & 3 \\
\hline
\end{tabular}




\begin{tabular}{|c|c|c|c|}
\hline & & Developing presentation techniques & 2 \\
\hline & & Learning why and how something will be done & 2 \\
\hline \multirow{3}{*}{ Partly } & \multirow{3}{*}{4} & Development if project is adopted & 3 \\
\hline & & Increasing in motivation of student if achievement is fulfilled & 2 \\
\hline & & Encouraging student if achievement is fulfilled & 2 \\
\hline \multirow{3}{*}{ No } & \multirow{3}{*}{7} & Losing the belief of success & 5 \\
\hline & & Putting student into trouble & 3 \\
\hline & & Breaking the flow of study & 2 \\
\hline
\end{tabular}

According to the data in Table 3, majority of teachers expressed that the students who participated into project competitions developed a scientific point of view. In the sense, mostly expressed views included students' reflecting scientific process steps into their life, their developing critical thinking skills, prompting to scientific thought, establishing causality, correlation and distribution relationships, and gaining the ability of geographical questioning. Some of the teachers mentioned their views as "partly" and "no". Views of some teachers were as: "I believe that scientific viewpoint develops in students who thoroughly make efforts for the project; because being in the process of creating a product through experiencing and practicing develops this point of view." $P 3$, "Yes, carrying out scientific researches related to the relevant projects and trying to prove thesis scientifically develop students' scientific point of view." P4, "I can observe the excitement in students. Making, creating and presenting things make them very happy. Being nested with science change their future plans; the ideas of presenting what they produce or their projects to the use of public or patenting of their project are very common." P20, "Scientific methods and techniques used during the preparation of projects are possible to be efficient upon development of scientific viewpoint in students. "P38.

3.3 Do Geography Teachers Think That the Sub-Structure of the Institution They Carry out Is Adequate for Preparing Projects?

Table 4. The views of geography teachers related to the adequacy of sub-structure of the institution they carry on their duties for preparing projects

\begin{tabular}{ll}
\hline Teacher Views & f \\
\hline Adequate & 15 \\
Inadequate & 9 \\
Partly inadequate & 8 \\
There is technical adequacy & 2 \\
Students have no opportunity to study at school & 2 \\
Both physical and human sources are inadequate & 2 \\
\hline
\end{tabular}

According to Table 4, majority of geography teachers considered the sub-structure of the institution they carried on their duty as adequate $(\mathrm{n}=15)$, partly adequate $(\mathrm{n}=8)$, and having technical adequacy $(\mathrm{n}=2)$ for preparing projects. On this subject, the teachers mentioned their views as: "The sub-structure is adequate; the responsibility is on teachers and students." (P4), "School management, teacher and students should study in cooperation." (P32), "The school has technical adequacy; however, because it is boarding school, the students have no chance to study out of the school." (P35).

Nearly half of the teachers who participated into the research $(n=13)$ mentioned that the institution they carried on their duty was inadequate for preparing projects, students had no chance to study at school, and the institutions were inadequate in terms of both physical and human resources. The teachers stated their views on this as: "I do not consider it is adequate. Unwillingness of students is a more serious problem." (P6), "I do not think it is adequate. Moreover, I consider that projects feel unwillingness on project preparation." (P7), "I do not think it is adequate. The institutions are inadequate in terms of both physical conditions and human resources." (P34). 
3.4 Do Geography Teachers Think That They Are Competent on Guiding the Students during the Process of Project Preparation?

Table 5. Competence of geography teachers for guidance during the process of preparing the project

\begin{tabular}{|c|c|c|c|}
\hline & & Teacher Views & $\mathbf{f}$ \\
\hline & & I am theoretically competent & 8 \\
\hline & & I participate into the process actively & 6 \\
\hline \multirow[t]{5}{*}{ Yes } & 13 & I am highly competent & 4 \\
\hline & & I consider that I am competent when I see the project & 3 \\
\hline & & I can manage the required guidance & 3 \\
\hline & & I consider that I am incompetent & 12 \\
\hline & & It required more knowledge and experience & 7 \\
\hline \multirow[t]{4}{*}{ No } & 17 & I have no project experience & 5 \\
\hline & & I will try after this seminar & 4 \\
\hline & & I have never engaged in this process & 2 \\
\hline & & I have weaknesses & 6 \\
\hline \multirow[t]{2}{*}{ Partly } & 8 & The seminars on this are significant & 4 \\
\hline & & We should be trained more on this. & 2 \\
\hline
\end{tabular}

The geography teachers who considered themselves as competent for guiding the students during the process of project preparation mentioned that they were competent theoretically, they actively participated into the process, and they were fairly competent for the process and the projects. The teachers stated their views on this as: "I think I am not competent for guidance. However, I consider that I can prepare project after the seminars provided to us." (P7), "I consider that I am competent in terms of my knowledge and equipment. When I see the projects ..." (P27).

Some of the teachers considered themselves as incompetent. The reason for this was project counseling's requiring more knowledge and experience and their not being included in the process before. The view of a teacher was as: "I do not think so. It requires more knowledge and study." (P35).

Some of the teachers answered as "partly" and expressed their views as "It is not possible to mention as fully competent, we have imperfections." (P22), "I believe that I can successfully manage this process because I have trained adequately in theory for the process of project preparation." (P29).

3.5 Do Geography Teachers Want to Make Their Students Carry out a Project at a Field Except from Geography? If Yes, on Which Field and Why not Geography?

Table 6. Views of geography teachers on counseling projects apart from their own fields

\begin{tabular}{|c|c|c|c|}
\hline \multirow{4}{*}{ Yes } & \multirow{4}{*}{5} & It can be a field I am competent & 2 \\
\hline & & It can be one of the fields of Physics, Chemistry, and Biology & 2 \\
\hline & & Geography is not a field appropriate for carrying out a project & 1 \\
\hline & & It can be on Sociology & 1 \\
\hline \multirow{3}{*}{ No } & \multirow{3}{*}{17} & Carrying out a project on your own field is essential & 12 \\
\hline & & It is not appropriate to carry out a project out of your field & 8 \\
\hline & & I prefer carrying out on my own field & 4 \\
\hline Partly & 8 & It depends on the interest of students & 8 \\
\hline
\end{tabular}


According to TUBITAK project directive, teachers are possible to counsel the projects not only on their own fields but also on other different fields. When the projects carried out all around Turkey were considered, this could be encountered frequently. Some of the geography teachers who participated into the research mentioned this to be possible. Some of the views were as: "It can be possible if I have adequate knowledge on Physics, Chemistry and Biology." (P5), "I do not think that geography is a field that is completely appropriate with carrying out a project." (P30).

Whereas nearly half of the geography teachers mentioned that teachers should make their students carry out projects in their own field, some other teachers mentioned that it was necessary to make students carry out projects according to the interests of the students. The views of teachers were as: "No, it is better to carry out projects in the field we know. It is difficult to make students carry out projects in a field out of our own."(P8), "I primarily carry out in geography if I have time." P20, "Because I have no adequate knowledge related to other fields, I do not want to make students carry out projects in others." (P38).

3.6 Are Projects Beneficial for the Future of the Students According to Geography Teachers?

Table 7. Views of geography teachers related to the contribution of projects upon the future of students

\begin{tabular}{|c|c|c|c|}
\hline \multirow{10}{*}{ Yes } & \multirow{10}{*}{27} & It is a very important experience & 16 \\
\hline & & It prompts to analyst-scientific thinking & 12 \\
\hline & & It is the first step for being a scientist & 7 \\
\hline & & The effort and troubles serve the purpose & 6 \\
\hline & & It develops the skill of problem solving & 5 \\
\hline & & It helps raising entrepreneur individuals & 5 \\
\hline & & It increases the self-confidence of students & 5 \\
\hline & & Thinking and analyzing abilities develop & 4 \\
\hline & & It helps breaking the prejudices down & 3 \\
\hline & & It teaches looking events from different viewpoints & 2 \\
\hline \multirow{3}{*}{ No } & \multirow{3}{*}{6} & It has no benefit & 5 \\
\hline & & I do not think so & 4 \\
\hline & & It is waste of time & 2 \\
\hline \multirow{3}{*}{ Partly } & \multirow{3}{*}{5} & In terms of some students & 4 \\
\hline & & Possible to be beneficial & 3 \\
\hline & & Maybe & 3 \\
\hline
\end{tabular}

According to the geography teachers, preparing project during high school period had multi-dimensional benefits for the future of the students. The leadings of these benefits were projects' being important experience, directing towards analyst-scientific thinking, being the first step towards being scientist, and development of problem solving skills. Some of teacher views were as: "The viewpoint towards the events broadens, and students learn minimizing the misapprehension." (P1), "Projects provide raising entrepreneur individuals with increased self-confidence. These provides decrease at statements of students such as I cannot manage, I cannot understand, that have been general in students." (P8), "Projects provide the development of thinking and solving abilities in educational dimension. They provide a significant motivation for students to attend into the ranks of scientists." (P27).

According to some of the teachers, project preparation did not provide benefits for the future of the students and this was a loss of time. Other teachers mentioned that projects could partly provide benefits, and this could change from one student to another. One view of the teacher was as: "A project team organized with students and studying together will be an experience for students they will not forget not only during their student life but during their whole life." (P33). 


\subsection{The Suggestions of Geography Teachers on Projects}

Table 8. Suggestions of geography teachers related to the projects

\begin{tabular}{ll}
\hline Teacher Views & $\boldsymbol{f}$ \\
\hline Financial support of project studies (while being prepared) & 10 \\
Enhancement of teacher trainings & 8 \\
Additional score, money rewards for the ones going on to the regional finals & 8 \\
Prioritizing the projects related to problem solving & 6 \\
Preparation of projects should be necessitated & 6 \\
High school process should not be completed before preparing a project & 5 \\
Seminars for students should be increased & 4 \\
Volunteer provincial project exhibitions should be organized & 3 \\
The students having role in projects should be encouraged at schools & 3 \\
Counseling units should be founded & 2 \\
Document procedures in projects should be decreased & 2 \\
More time should be taken on projects & 2 \\
Project-like studies should be increased at schools & 1 \\
\hline
\end{tabular}

When Table 8 was analyzed, the leadings of the suggestions teachers offered for the projects were being financially supported during the project studies, increasing teacher trainings, additional score and money rewards for the ones going on to the regional finals, prioritizing the projects related to problem solving, and necessitating of project preparation. Views of some teachers were as: "Giving at least rewards such as additional scores and money to teachers and students who have projects going on to the regional finals will increase the number of projects." P6, "Graduating from high school without carrying out a project should be complicated making projects necessary. However, interest and eagerness of both students and teachers could be increased in this way." 99 , "Teachers can prepare projects in association with academicians in order to gain experience, and hold exhibitions in their province (out of competition, optional)." P20, "I consider that viewpoints of teachers upon projects should primarily be changed. When the viewpoint changes very different and efficient projects will appear in terms of content and implementation." P27, "having no adequate time and many lessons decreases the number of students who want to carry out projects." P31.

\section{Discussion and Suggestions}

According to the findings obtained in this study, it was revealed that participating into scientific project competitions was very beneficial for the students. According to Karadeniz and Ata (2013), it was noticed that the students who attended to Social Sciences lesson project fair experienced feelings such as fear/anxiety/worry and excitement much, and the feelings such as proud, curiosity, sadness, sorrow, hope, ambition and stress were subsequent. The most significant point that drew attention was students' experiencing happiness while feeling fear. This could be interpreted in a way that students experienced fear while preparing to the Social Sciences Project Fair; however, this fear turned into happiness on fair day. According to Karadeniz (2015), science fairs provided students pragmatic acquisitions such as communicating, studying in cooperation, gaining self-confidence, planned studying, expressing themselves, etc. Moreover, they enabled students to use scientific research methods and experience increase in their interests towards science and scientists.

The teachers considered that participating into scientific project competitions developed viewpoints of the students in terms of several aspects. Karadeniz and Ata (2013) reported that projects were possible to be better in case more equipment and materials were provided, presentations were made in a more appealing to the eye way, more support was provided, more time and researching opportunities were offered, awareness on the process was increased, and projects were diversified.

Whereas the institutions they worked were adequate for developing projects according to most of the geography teachers, other teachers considered the institutions as inadequate. Because project studies required a process that should be organized well and planned in details, and each stage should be followed elaborately. 
Whereas most of the geography teachers considered themselves as competent for guidance during the process of project preparation, the teachers who regarded themselves as inadequate tried to develop themselves. In his research, Tortop (2013) revealed the roles a counselor should have in projects competitions as managing, complementary for teachers and students, motivating, solving the problems, supportive, skill developed and helper. The role of the counselor was determined as motivating by the managers, as directing by the teachers and as supporting by the students.

Whereas some of the geography teachers thought that they could guide projects with topics of different disciplines than the one of their expertise, this was regarded as as negative by the majority. According to Korkmaz (2004), science fairs were organizations in which students projects were presented and shared with the opportunity of individuals' direct participation during the research process. Although a science fest had several didactic properties, the basic purpose of these fests was developing scientific thinking, and encouraging individuals learning to use scientific method and researching.

Carrying out projects provides very significant experiences and benefits for the future of students. According to Cicek (2008), desires of students for proving themselves, creating a product and achieving direct them towards playing an energizing role in such activities. In this way, productivity is enhanced more than expected is provided in such studies in general. According to Yayla and Uzun (2008) science fests had benefits upon the students such as teaching new things, having amusing time, developing researching skills, thinking critically and developing positive attitude towards the science. Nevertheless, these had also disadvantages such as causing sorrow, stressing and increasing the anxieties at the end of the competition. Using the ways of reaching to information and looking into events through a critical approach rather than transferring information as it is are in nature of project-based learning and science fests. As result of the activities, students reach to information with their own efforts and have the chance of revising their knowledge at a critical dimension.

In this sense, the suggestions below can be offered:

- Additional score in exams should be provided not only in field of the students but in any field students will make preference.

- Besides the project counseling trainings for the teachers, student trainings should also be emphasized.

- The students who do not attend to project fairs besides the ones who attend should be included into this process through the activities such as visiting the fair, and providing information support for their friends, and appropriate conditions for making them gain these skills should be provided.

- Projects should be supported by both public and private institutions, and participation of the students into these organizations should be provided increasing the number of such organizations.

\section{References}

Ata, B. (2009). "Sosyal bilgiler ünitesi” kavramı üzerine bazı düşünceler [Some thoughts on the concept of "social science unit”]. In R. Turan, A. M. Sünbül, \& H. Akdağ (Eds.), Sosyal bilgiler ögretiminde yeni yaklaşımlar (pp. 35-37). Ankara: Pegem Akademi.

Bloor, M., \& Wood, F. (2006). Keywords in Qualitative Methods: A Vocabulary of Research Concepts, London. https://doi.org/10.4135/9781849209403

Camc1, S. (2008). Bilim şenliğine katılan ve katılmayan ögrencilerin bilim ve bilim insanlarına yönelik ilgi ve imajlarının karşılaştırlması [Comparison of the interest and image of students who participate in science festival and those who do not participate in science festival]. Yayımlanmamış yüksek lisans tezi, Hacettepe Üniversitesi Sosyal Bilimler Enstitüsü, Ankara.

Cicek, S. (2008). Lise 2 ögrencilerinin kimya dersinde başarıları ve tutumları üzerine bilim şenliklerinin etkisinin incelenmesi [Investigation of the effects of science festivals on the success and attitudes of high school 2 students in chemistry lessons]. Yayımlanmamış yüksek lisans tezi, Gazi üniversitesi Eğitim Bilimleri enstitüsü, Ankara.

Creswell, J. W. (2013). Beş Yaklaşıma Göre Nitel Araştırma ve Araştırma Deseni [Qualitative Research and Research Design according to Five Approaches] (M. Bütün \& S. B. Demir, Çev. Ed.). Nitel Araştırma Yöntemleri, Ankara: Siyasal Yayınevi.

Demirel, O. (2003). Eğitim Sözlüğü [Dictionary of Education]. Ankara: PegemA Yayınc1lık.

Karadeniz, O. (2012). Sosyal Bilgiler proje fuarının sosyal bilgiler dersine ilişkin tutumlara etkisi ve sürece yönelik ögrrenci, ögretmen ve veli görüşleri [Effects of the social studies project fairs on the attitudes 
towards the social studies course and student, teacher and parent views on the process]. Yayımlanmamış doktora tezi, Gazi Üniversitesi Eğitim Bilimleri Enstitüsü, Ankara.

Karadeniz, O. (2015). Okul Dışı Sosyal Bilgiler Öğretiminde Bilimsel ve Sanatsal Etkinlikler [Scientific and Artistic Activities in Teaching Social Studies Out of School]. In A. Şimşek, \& S. Kaymakçı (Eds.), Okul Dışı Sosyal Bilgiler Öğretimi (pp. 367-388). Ankara: Pegem Akademi.

Karadeniz, O., \& Ata, B. (2013). Sosyal Bilgiler Dersinde Proje Fuarının Kullanılmasına İlişkin Öğrenci Görüşleri [The Students Interviews on The Use of the Project Fair in Social Studies Lesson]. Adlyaman Üniversitesi Sosyal Bilimler Enstitüsü Dergisi, 6(14), 375-410. https://doi.org/10.14520/adyusbd.607

Korkmaz, H. (2004). Fen ve Teknoloji Eğitiminde Alternatif Değerlendirme Yaklaşımları [Alternative Evaluation Approaches in Science and Technology Education] (pp. 79-92). Ankara: Yeryüzü Yayınevi.

Kurak, D. (2009). Illköğretim Dördüncü ve Beşinci Sinıf Öğrencilerinin Yaptı̆̆ Proje Çalışmalarının Öğretmen ve Ögrrenci Görüşlerine Göre Değerlendirilmesi [Evaluation of the Project Activities of the Fourth and Fifth Grade Primary School Students in Terms of Teacher and Student Opinions]. Yayımlanmamış yüksek lisans tezi, Çukurova Üniversitesi Sosyal Bilimler Enstitüsü, Adana.

Maguth, B. M., \& Yamaguchi, M. (2010). Beyond the surface: A guide to substantive world fairs in the social studies. The Social Studies, Taylor \& Francis Group, 76-78. https://doi.org/10.1080/00377990903284062

Morgil, İ., Yavuz, S., \& Oskay, Ö. Ö. (2006). The Effects of Project-Based Learning Applications on Environmental Awareness and Knowledge. Energy Education Science and Technology, 16(1), 9-19.

Ozden, Y. (2002). Ĕ̌̆itimde dönüşüm, eğitimde yeni değerler [Transformation in Education, New Values in Education]. Ankara: Pegem A Yayıncilık.

Ozturk, T. (2011). Sosyal Bilgiler ögrretiminde projeye dayalı ögrenme yaklaşımının öğrencilerin başarısına, derse karşı tutumlarına ve görüşlerine etkisi [Effect of project-based learning approach in social studies teaching to the success of students, attitudes towards their classes and opinions]. Yayımlanmamış doktora tezi, Gazi üniversitesi Eğitim Bilimleri enstitüsü, Ankara.

Tortop, H. S. (2013). Bu Benim Eserim Bilim Şenliğinin Yönetici, Öğretmen, Öğrenci Görüşleri ve Fen Projelerinin Kalitesi Odağından Görünümü [Overvıew of a natınal science fair in turkey from the focus on adminıstrators', teachers', students' views and quality of science projects]. Adiyaman Üniversitesi Sosyal Bilimler Enstitüsü Dergisi, 6(12), 35-88.

TUBITAK. (2011). Proje Rehberi. Retrieved http://www.tubitak.gov.tr/tubitak_content_files//BIDEB/proje_yarismasi/proje_rehberi_2012.pdf

TUBITAK. (2016a). Proje Rehberi. $\quad$ Retrieved from https://www.tubitak.gov.tr/tr/yarismalar/icerik-lise-ogrencileri-arastirma-projeleri-yarismasi

TUBITAK. (2016b). Bilim ve Teknik Dergisi [Science and Technical Magazine], 50(588), 7.

Turk Dil Kurumu. (1998). Türkçe Sözlük [Turkish Dictionary]. Ankara: Türk Dil Kurumu Yayınları.

Vyhmeister, N. (2008). Quality Research Papers for Students of Religion and Theology. Michigan: Zondervan Edition.

Yavuz, S., Büyükekşi, C., \& Büyükekşi, S. I. (2014). Bilim Şenliğinin Bilimsel İnanışlar Üzerine Etkisi [Effect of Science Fair on Epistemological Beliefs]. Karaelmas Egitim Bilimleri Dergisi, 2, 168-174.

Yayla, Z., \& Uzun, B. (2008). Fen ve teknoloji eğitiminde proje çalışmaları ve bilim şenlikleri [Project studies and science festivals in science and technology education]. Ulusal eğitim bilimleri kongresi, Sakarya.

Yildirim, A., \& Simsek, H. (2011). Sosyal Bilimlerde Nitel Araştırma Yöntemleri [Qualitative research methods in the social sciences]. Ankara: Seçkin Yayınevi.

\section{Copyrights}

Copyright for this article is retained by the author(s), with first publication rights granted to the journal.

This is an open-access article distributed under the terms and conditions of the Creative Commons Attribution license (http://creativecommons.org/licenses/by/4.0/). 